\title{
Different Techniques of Harvesting Connective Tissue Graft: An Update
}

\section{Diksha R. Agrawal'1, ${ }^{\text {, }}$ riyanka Jaiswal²}

Section: Healthcare

Sci. Journal Impact

Factor: 6.1 (2018)

ICV: 90.90 (2018)

\begin{abstract}
'Postgraduate student, Department of Periodontics, Sharad Pawar Dental College and Hospital, Datta Meghe Institute of Medical Science (Deemed to be University), Sawangi (Meghe), Wardha, Maharashtra, India; ${ }^{2}$ Associate Professor, Department of Periodontics, Sharad Pawar Dental College and Hospital, Datta Meghe Institute of Medical Science (Deemed to be University), Sawangi (Meghe), Wardha, Maharashtra, India.
\end{abstract}

\section{ABSTRACT}

Objective: The objective of this review article is to illustrate numerous technique for harvesting SCTG.

Overview: Reconstruction of soft tissue defect around the teeth and implants through soft tissue grafting procedures have become crucial for periodontal surgeries. The subepithelial connective tissue graft (SCTG) has been a gold standard for perioesthetic surgery and regarded as reliable and predictable. Since the surgical procedure is technically demanding, the clinician has to be well versed in diverse aspects of the procedure, including handling of the tissue, knowing the potential limitations, and avoiding complications associated with the technique.

Conclusion: The easy availability, low cost, and proven efficacy of SCTGs compared to other regenerative techniques have made this a valuable approach to periodontal plastic surgery.

Clinical Significance: The SCTG is inexpensive, versatile, easily available and less invasive. As it provides predictable outcomes. The superior esthetics and predictable outcomes obtained through SCTG is the gold standard for treatment of root coverage.

Key Words: Subepithelial connective tissue graft, Harvesting technique, Graft harvesting, Incision, Connective tissue

\section{INTRODUCTION}

Periodontal plastic surgery comprises several techniques for the management of soft tissue deficits and deformities. ${ }^{1}$ Among these are insufficient clinical crown length, asymmetric gingival margins, improper gingival margin relationship, localized alveolar ridge deficiencies, gingival pigmentation, exposure of unerupted teeth and localized marginal tissue recession. ${ }^{2}$ Of these, gingival recession is a long-recognized condition that has been addressed in the literature via a variety of surgical techniques. The primary concerns regarding the presence of gingival recession include marginal tissue irritation, root surface sensitivity, root caries, esthetic concerns and loss of a tooth. Updates in materials and techniques have resulted in improvements in esthetics and predictability.

Connective tissue (CT) grafts are one of the most widely used therapeutic strategies today in periodontal plastic surgery. In Europe Bjorn ${ }^{3}$ introduced technique for soft tissue augmentation using Free gingival graft (FGG). B jorn ${ }^{3}$ was the first to report the transplantation of epithelialized palatal grafts to augment the zone of keratinized gingiva. Harvey ${ }^{4}$ proposed the technique in which a combination of FGG followed by a Coronally Positioned Flap (CPF) was used to augment the amount of attached tissue. Miller et al.(1985) expanded on the technique and utilized FGG in root coverage procedures. ${ }^{5}$ However, these may cause additional surgery, operating time, and expenditure. Also, FGG tends to yield an unacceptable colour match to gingiva and keloid appearance during healing. Thus, FGG considered unsuitable for covering denuded roots.

Grupe and Warren ${ }^{6}$ first reported lateral sliding flap procedure for the management of gingival recession. This procedure was restricted by the amount and thickness obtained adjacent from donor tissue. Cohen and Ross ${ }^{7}$ put forward the Double Papilla Flap in 1968. Both these techniques are not advised if sufficient adjacent keratinized tissues do not exist.

\section{Corresponding Author:}

Dr. Diksha R. Agrawal, Postgraduate student, Department of Periodontics, Sharad Pawar Dental College and Hospital, Datta Meghe Institute of Medical Science (Deemed to be University), Sawangi (Meghe), Wardha, Maharashtra, India.

ISSN: 2231-2196 (Print)

Received: 16.05 .2020
ISSN: $0975-5241$ (Online)

Revised: 12.06 .2020

Accepted: 02.07 .2020
Published: 08.08 .2020 
Edel ${ }^{8}$ was the first to address these concerns by obtaining subepithelial connective tissue graft (SCTG) for the augmentation of keratinized gingiva. Langer and Calagna ${ }^{9}$ proposed SCTG procedure for augmentation of soft tissue and the combination of SCTG with pedicle graft for root coverage was developed by Langer and Langer. ${ }^{10}$

Various modified technique for harvesting the graft and its use at the recipient site was put forward. Over the period, most reliable outcomes for root coverage were obtained through SCTG. ${ }^{11}$ Allen et al. ${ }^{12}$ stated that the combination of SCTG with coronally positioned flap showed a significantly greater outcome for the treatment of multiple gingival recession with root coverage ranging from $82-100 \%$.

Major advantages of the SCTG are that it is inexpensive, versatile, and easily available; it provides successful outcomes; it is less invasive than other autogenous harvesting techniques, and it has a shorter healing period. ${ }^{13-14}$

\section{Other benefits of the SCTG are}

1) The graft has a dual blood supply.

2) The SCTG provides better colour matching and surface topography and hence improved esthetic integration. ${ }^{14}$

3) The donor site heals with primary intention, resulting in less scarring. ${ }^{14}$

4) The SCTG has greater predictability.

5) The procedure causes minimal discomfort to the patient, and the site heals rapidly.

6) The SCTG is quick, user friendly, and easy to utilize in various situations. ${ }^{15}$

7) The SCTG is a versatile procedure. It has multiple applications, ranging from extensive soft tissue ridge augmentation to procedures as small as papilla reconstruction and management of peri-implant tissues.

\section{Indications for SCTG are ${ }^{16}$}

1) Management of soft tissue recession around teeth and implants

2) Augmentation of the zone of keratinized gingiva

3) Use of soft tissue for ridge augmentation

4) Preservation of the ridge with the implant and fixed partial dentures procedure

5) Augmentation of gingival thickness following or before orthodontic therapy

6) Augmentation of gingival thickness following or prior to restorative therapy

7) Reconstruction of soft tissue and coverage of maxillary defects

8) Surgical reconstruction of interdental papilla

9) Management of peri-implant tissues

10) Closure of defects following an apicoectomy

11) Intraosseous subperiosteal connective tissue graft for reduction of pockets and management of furcations as combined procedures
12) Correction of localized gingival pigmentation

13) Masking of discoloured roots or visible implant components

Bassetti et al. ${ }^{17}$ in a systematic review evaluated the effectiveness for augmentation of soft tissue during 2 nd stage surgery in respect to increasing the peri-implant zone of keratinized mucosa (KM) and/or increase in the size of soft tissue. The authors concluded that application of apically positioned partial-thickness flap (APPTF) to increase keratinized mucosa and the roll envelope flap increases soft tissue volume at the buccal side of the implant are effective in the upper jaw. Also in the lower jaw, to increase the zone of keratinized mucosa use of APPTF combined with FGG or a xenogeneic graft material gives predictable outcomes.

Poskevicius L et al. ${ }^{18}$ in their systematic review evaluated changes in keratinized mucosa width after grafting of soft tissue and soft tissue thickness all over the dental implants. The authors concluded that there was again in the zone of keratinized mucosa and thickness of soft tissue was obtained under an observation period of 2 years

The SCTG does have several limitations:

1) Harvesting the graft is contraindicated in the presence of a narrow palatal vault, thin palatal tissue, or bony exostosis. ${ }^{19-20}$

2) Production of an adequately sized graft is not always possible.

3) Existence of a second surgical site increase patient morbidity

\section{Anatomical considerations}

- The hard palate is composed of the horizontal process of the palatal bone and the palatine process of the maxillary bone and it is enclosed with masticatory mucosa. $^{21}$

- The soft tissue extends above from the cementoenamel junction (CEJ) of upper posterior teeth. Dense lamina propria present is of 2 to $4 \mathrm{~mm}$. At the midline, glandular and adipose tissue present in connective tissue. ${ }^{22}$

- Thickest tissue is present in the area from the line angle of the mesial side of the palatal root of the first molar to the distal side of the canine.

- Greater and lesser palatine nerves and blood vessels pass via greater and lesser palatine foramina into the palate. These nerves and vessels course anteriorly within a bony groove. The groove is easiest to palpate at its most posterior extent.

Klosek et al. ${ }^{23}$ investigated the topography of structures of the palate like foramen and artery of greater palatine, incisive fossa for planning the graft dimensions and preventing the risk of injury of the greater palatine artery. The authors observed that the position of greater palatine foramen was $35.7 \%$ present in between $2^{\text {nd }}$ and $3^{\text {rd }}$ molars with female predilection and $65 \%$ present palatal to $2^{\text {nd }}$ molar with a 
male predilection. They also found ease in harvesting graft of about $5 \mathrm{~mm}$ interproximal to $1 \mathrm{st}$ premolar and $2^{\text {nd }}$ molar. This research helps in assisting periodontologists in planning the thickness, volume and harvesting the connective tissue grafts from the palatal donor site.

Donor tissue thickness of harvesting SCTG categorized into three types-

1. Thin $(0.5-0.8 \mathrm{~mm})$

2. Average $(0.9-1.4 \mathrm{~mm})$

3. Thick $(1.5$ to $>2 \mathrm{~mm})$

After surgery, the amount of shrinkage and the rate of healing of the SCTG depends on the thickness of the graft. Rapid revascularization on a periosteal recipient site can occur through the placement of the uniform thin graft. However, placement of uneven thick graft on denuded bone leads to a lengthened period of revascularization and delayed healing. ${ }^{24}$

\section{Surgical considerations and harvesting tech- niques}

Edel first described palatal harvesting technique of SCTGs to gain the width of the attached gingiva. ${ }^{8}$ Subsequently, various techniques for harvesting the graft from different oral sites have been proposed. Intraoral donor sites selected for SCTG harvesting must offer adequate obtainable tissue. SCTGs are most commonly harvested from the palatal mucosa, but other areas, such as the maxillary tuberosity, can also be utilized. ${ }^{25}$

The techniques used to harvest SCTGs differ in number and type of surface incisions, ways to gain access to the graft, and flap designs. Depending on the number and condition of mucous membrane and its vascular supply, flap design is three dimensional tissue which is independent of the wound bed and flap tissue. ${ }^{26}$

Each SCTG procedure has pros and cons, and the technique selected depends on various parameters, such as the objective of the procedure, expected morbidity, existing anatomical limitations and surgeon's skill. ${ }^{26-27}$

Incision design classification for the palatal donor site is based upon-

1. A requirement of graft size for recipient bed site

2. Palatal vault anatomy ${ }^{20}$

3. Presence of an exostosis ${ }^{28}$

4. Donor site healing through the primary or secondary intention of healing ${ }^{15}$

5. The blood supply for flap coronally positioned above the graft

6. Postsurgical distress

Liu and Weisgold have proposed a classification for graft harvesting from the palate, based on the number of incisions (Table 1 and 2). ${ }^{29}$

Table 1: Classification for graft harvesting from the palate

\begin{tabular}{|c|c|c|c|}
\hline Type of Incision & Indication & Advantages & Disadvantages \\
\hline Class I- One incision line & $\begin{array}{l}\text { Class I used for harvesting any } \\
\text { type of SCTG from the palatal } \\
\text { site }\end{array}$ & $\begin{array}{l}\text { 1. Only } 1 \text { incision line used } \\
\text { 2. No need for acrylic stent post- } \\
\text { operatively. } \\
\text { 3. Haemostatic agents and Sutures } \\
\text { are not required } \\
\text { 4. The incision can be placed to } \\
\text { different forms of palatal vault. } \\
\text { 5. Less patient distress. } \\
\text { 6. Provides more blood supply for } \\
\text { the overlying flap (Donor site) } \\
\text { 7. Wound healing through } \\
\text { primary closure seen in Class I } \\
\text { type A }\end{array}$ & $\begin{array}{l}\text { 1. Less visibility of donor site } \\
\text { 2. Quite challenging to } \\
\text { perform }\end{array}$ \\
\hline
\end{tabular}

Class II- Two incision

lines

(L shape)

To prevent injury to greater palatine artery and nerve

Class III- Three incision lines

(U shape)
1. Interest for underlying anatomy includes exostosis, vessels, nerves

2. The requirement of a longer amount of tissue
1. Provide proper visibility due to smaller incision

2. No need for third incision line

3. Provide adequate blood supply for the overlying flap (Donor site)

4. Ease to perform

1. The similarity in graft size and incision design.

2. More visibility

3. Relatively easy to perform
Due to two incision lines may cause hindrance to supply of blood from the palatal donor site.

\footnotetext{
1. Added incision lines can hamper the supply of blood to the donor site.

2. Provide postoperative discomfort.

3. Need for stent or suture
} 
Table 1: (Continued)

\begin{tabular}{|c|c|}
\hline Type of Incision & Disadvantages \\
\hline \multicolumn{2}{|c|}{ Subclassification (horizontal incision) } \\
\hline $\begin{array}{l}\text { Type A (one horizontal } \\
\text { incision) design }\end{array}$ & $\begin{array}{l}\text { Indications: } \\
\text { 1. The requirement of connective tissue }(\mathrm{CT}) \text { graft without covering of epithelium } \\
\text { 2. Indicated in various forms of palatal vault } \\
\text { 3. Applied in the site of a minimum depth of tissue (Average tissue of molar area is } \leq 3 \mathrm{~mm} \text { ) } \\
\text { 4. When the requirement of SCTG length more than two premolars or more than the normal depth } \\
\text { of tissue with the use of one incision line to harvest more amount of SCTG. }\end{array}$ \\
\hline $\begin{array}{l}\text { Type B (two horizontal } \\
\text { incisions) design }\end{array}$ & $\begin{array}{l}\text { Indications: } \\
\text { 1. The palatal tissue is of adequate thickness. } \\
\text { 2. The requirement of connective tissue graft with epithelial covering and recipient site should } \\
\text { expose the epithelial side of the graft }\end{array}$ \\
\hline
\end{tabular}

Table 2: Types of incisions with examples

\begin{tabular}{|c|c|}
\hline Type of incision & Examples \\
\hline Class I (one incision lines) & $\begin{array}{l}\text { Hürzeler and Weng } 1999^{32} \\
\text { Lorenzana and Allen } 2000^{34} \\
\text { Del Pizzo 2002 } \\
\text { Ribeiro et al. } 2008^{37} \\
\text { Kumar A et al. } 2013^{39}\end{array}$ \\
\hline Class II (two incision lines) & Bruno $1994^{33}$ \\
\hline Class III (three incision lines) & $\begin{array}{l}\text { Edel } 1974^{8} \\
\text { Langer and Calagna } 1980^{9} \\
\text { Harris } 1992^{3^{1}}\end{array}$ \\
\hline Subclass type B & $\begin{array}{l}\text { Langer and Langer } 1985^{10} \\
\text { Raetzke } 1985^{30}\end{array}$ \\
\hline
\end{tabular}

Harvesting techniques for SCTG from the palate (Table 3)

Table 3: Harvesting techniques for SCTG from the palate

\begin{tabular}{|c|c|}
\hline Author (year) & Harvesting technique \\
\hline Edel $(1974)^{8}$ & $\begin{array}{l}\text { Trapdoor technique. The palatal portion op- } \\
\text { posite to the molars is selected for harvest- } \\
\text { ing the graft. A primary incision is given near } \\
\text { gingival margin to the long axis of the teeth. } \\
\text { For harvesting graft, } 1 \text { horizontal and } 2 \text { vertical } \\
\text { incisions given. The incision under the surface } \\
\text { of an edentulous region can also be used for } \\
\text { harvesting the graft. Complete wound closure is } \\
\text { achieved }\end{array}$ \\
\hline
\end{tabular}

Langer and Calagna (1980) ${ }^{9}$

\begin{abstract}
A horizontal incision is given on palate $1 \mathrm{~mm}$ apical to gingival margin of posterior teeth followed by vertical incision at either end for SCTG harvesting. If there is a presence of periodontal pocket elimination, an internal bevel incision given for pocket removal. From the excised pocket wall, connective tissue and epithelium are recovered. The band of the epithelium in the harvested tissue is discarded, while connective tissue is retained.
\end{abstract}

\section{Advantage Disadvantage}

Need for similar graft size It was common to observe and incision design, to increase visibility, easy to execute.

flap necrosis, prolonged pain and discomfort, the Blood supply of overlying flap get hampered due to vertical incision and may cause sloughing of the palatal flap.

It helps in augmentation of concavities and irregularities in edentulous ridges for cosmetic purpose

1. Height and contour of pontics of the temporary prosthesis must be altered after surgical procedure.

2. For the esthetic purpose, gingivoplasty may be essential to decrease irregularity. 
Table 3: (Continued)

\begin{tabular}{|c|c|c|c|}
\hline Author (year) & Harvesting technique & Advantage & Disadvantage \\
\hline $\begin{array}{l}\text { Langer and Langer } \\
(1985)^{10}\end{array}$ & $\begin{array}{l}\text { Two horizontal and two vertical incisions are } \\
\text { given, a rectangular design which results in an } \\
\text { SCTG with an epithelial collar of } 1.5-2.0 \mathrm{~mm} \text { in } \\
\text { width. }\end{array}$ & $\begin{array}{l}\text { 1. Donor site heals with } \\
\text { less discomfort } \\
\text { 2. Not require a periodon- } \\
\text { tal pack } \\
\text { 3. The gain in root cover- } \\
\text { age } 2-6 \mathrm{~mm}\end{array}$ & $\begin{array}{l}\text { This technique performed } \\
\text { in patients with an excellent } \\
\text { level of plaque control. }\end{array}$ \\
\hline Raetzke $(1985)^{30}$ & $\begin{array}{l}\text { 1. This technique employs no vertical inci- } \\
\text { sions but } 2 \text { converging horizontal, crescent- } \\
\text { shaped incisions intersect deeply in the } \\
\text { palate. } \\
\text { 2. A wedge of tissue is removed and the small } \\
\text { band of epithelium is excised. }\end{array}$ & $\begin{array}{l}\text { 1. The gain of keratinized } \\
\text { gingiva } \\
\text { 2. Donor site heals with } \\
\text { less discomfort }\end{array}$ & $\begin{array}{l}\text { 1. Healing is not achieved } \\
\text { through primary closure } \\
\text { of the wound. } \\
\text { 2. This technique provides } \\
\text { a better healing wound } \\
\text { than the trapdoor } \\
\text { technique but makes it } \\
\text { difficult to obtain CT } \\
\text { grafts of ample size to } \\
\text { solve large defects. } \\
\text { 3. } \begin{array}{l}\text { complete primary } \\
\text { closure of the wound } \\
\text { cannot predictably be } \\
\text { obtained. }\end{array}\end{array}$ \\
\hline Harris $(1992)^{3^{1}}$ & $\begin{array}{l}\text { Graft knife technique/Harris double-blade } \\
\text { technique. } \\
\text { 1. This modification of the original trapdoor } \\
\text { technique was done to raise partial-thick- } \\
\text { ness flap by use of graft knife. } \\
\text { 2. The knife is placed at the distal portion of } \\
\text { connective tissue and then pulled mesially }\end{array}$ & $\begin{array}{l}\text { It provides a graft of pre- } \\
\text { dictable and uniform width. }\end{array}$ & $\begin{array}{l}\text { It is, however, difficult to } \\
\text { perform in one single } \\
\text { stroke following the palatal } \\
\text { vault curvature, and some } \\
\text { connective the tissue is lost } \\
\text { while removing the epithe- } \\
\text { lium. }\end{array}$ \\
\hline
\end{tabular}

Hürzeler and Weng $(1999)^{32}$ under the trapdoor flap, to elevate a connective tissue.

3. The technique can be simplified by utilizing a Harris double-bladed graft knife in which two blades are mounted $1.5 \mathrm{~mm}$ apart.

Single-incision technique

1. A single horizontal incision is given $2 \mathrm{~mm}$ apical to marginal gingiva on the palate.

2. Initially, the blade is angled 90 degrees, and then it is angled to 135 degrees to undermine the flap.

3. The SCTG is removed by making the incision to the bone on all sides of the uncovered SCTG.
Advantage

This technique performed in patients with an excellent Not require a periodon- level of plaque control pack

age $2-6 \mathrm{~mm}$

The gain of keratinize

2. This technique provides a better healing wound than the trapdoor difficult to obtain CT grafts of ample size to solve large defects. closure of the wound cannot predictably be ained.

It provides a graft of preperform in one single ke following the palata connective the tissue is lost lium.

1. Optimal vascularization of the cover flap

2. A small number of the suture is required

3. Painless wound healing

4. Possibility of obtaining grafts of variable dimension

5. Postoperative healing is better

6. Patient morbidity is decreased. pends on the angula-
1. The author advocated ist incision to the bone which causes trauma to connective tissue and blood vessels in it.

2. It leads to haemorrhage and hampers visibility.

3. To achieve a thickness of the subepithelial connective tissue, it detion of blade after ist incision.

4. Followed by 1st incision, blade angulation placed at 135 degrees to the bone for harvesting sub epithelial connective tissue graft.

5. It does not provide visibility. Such incisions do not provide a uniform thickness of the graft. 
Table 3: (Continued)

\begin{tabular}{|c|c|c|c|}
\hline Author (year) & Harvesting technique & Advantage & Disadvantage \\
\hline Bruno $(1994)^{33}$ & $\begin{array}{l}\text { Double-incision technique } \\
\text { 1. The first incision is given } 2-3 \mathrm{~mm} \text { below the } \\
\text { margin of gingival of upper teeth, falling just } \\
\text { short of bone. } \\
\text { 2. The second incision is given } \mathbf{1 - 2} \text { mm below } \\
\text { to ist incision and made angulation parallel } \\
\text { to the long axis of the teeth. } \\
\text { 3. A small size periosteal elevator was used to } \\
\text { raise a mucoperiosteal SCTG. }\end{array}$ & $\begin{array}{l}\text { 1. Prevents lifting of the } \\
\text { mucosal flap } \\
\text { 2. Minimizes post-opera- } \\
\text { tive complications } \\
\text { 3. Promotes rapid healing. }\end{array}$ & $\begin{array}{l}\text { Avoiding the use of vertical } \\
\text { incision increases the dif- } \\
\text { ficulty of } \\
\text { procedure. }\end{array}$ \\
\hline $\begin{array}{l}\text { Lorenzana and } \\
\text { Allen }(2000)^{34}\end{array}$ & $\begin{array}{l}\text { 1. This technique is identical to the technique } \\
\text { given by Hürzeler and Weng, except that } \\
\text { vertical (mesial and distal) } \\
\text { 2. Medial incisions are not made to relieve the } \\
\text { graft. } \\
\text { 3. A small moult elevator is used to raise the } \\
\text { connective tissue with underlying perios- } \\
\text { teum. } \\
\text { 4. Careful manipulation of the graft with Corn } \\
\text { suture pliers or other delicate tissue forceps } \\
\text { are required. Proper care should be taken to } \\
\text { prevent compression or tearing of graft. }\end{array}$ & $\begin{array}{l}\text { 1. Rapid palatal healing } \\
\text { 2. More conservative and } \\
\text { less traumatic for the } \\
\text { patient } \\
\text { 3. Reducing palatal dis- } \\
\text { comfort }\end{array}$ & $\begin{array}{l}\text { If large augmentation } \\
\text { of keratinized gingiva is } \\
\text { required, retention of the } \\
\text { epithelial collar may be } \\
\text { desired }\end{array}$ \\
\hline $\begin{array}{l}\text { Del Pizzo et al. } \\
(2002)^{35}\end{array}$ & $\begin{array}{l}\text { A single incision is made on the bone to surface } \\
\text { of palate perpendicularly. The parallel incision } \\
\text { was given to long axis of teeth for split-thickness } \\
\text { dissection to dissect the graft from superficial } \\
\text { tissues and underlying bone. No blunt dissec- } \\
\text { tion with periosteal elevator is made, leaving the } \\
\text { periosteum intact on the surface of the bone. } \\
\text { This aids in the development of granulation tis- } \\
\text { sue at the lesion site and restore the donor site. }\end{array}$ & $\begin{array}{l}\text { 1. Faster epithelization } \\
\text { 2. achieved complete epi- } \\
\text { thelization at } 3 \text { weeks } \\
\text { postoperatively } \\
\text { 3. Complete sensibility } \\
\text { was recovered }\end{array}$ & $\begin{array}{l}\text { 1. Postoperative discomfort } \\
\text { due to the palatal wound } \\
\text { 2. Postoperative bleeding }\end{array}$ \\
\hline $\begin{array}{l}\text { Bosco and Bosco } \\
(2007)^{3^{6}}\end{array}$ & $\begin{array}{l}\text { Partial-thickness flap was reflected from edges, } \\
\text { 1.5-mm incision given by keeping the perios- } \\
\text { teum intact. A thick connective tissue graft } \\
\text { harvested consist of connective tissue with the } \\
\text { covering of epithelium. The graft is placed on } \\
\text { sterile cloth and bisected. One of the resulting } \\
\text { grafts consists of the epithelium with connective } \\
\text { tissue, while the other consists only of connec- } \\
\text { tive tissue. The epithelial graft is repositioned at } \\
\text { donor site like a free gingival graft and peri- } \\
\text { odontal dressing is placed. }\end{array}$ & $\begin{array}{l}\text { 1. It demonstrates the } \\
\text { viability and safety of } \\
\text { obtaining large graft } \\
\text { in patients with thin } \\
\text { palatal mucosa } \\
\text { 2. Allows harvesting a very } \\
\text { large connective tissue } \\
\text { graft in one piece }\end{array}$ & $\begin{array}{l}\text { Technique sensitive proce- } \\
\text { dure. }\end{array}$ \\
\hline $\begin{array}{l}\text { Ribeiro et al. } \\
(2008)^{37}\end{array}$ & $\begin{array}{l}\text { Tunnel Technique } \\
\text { 1. By use of the single-incision technique, the } \\
\text { SCTG was harvested with maximum thick- } \\
\text { ness so that it can be split cross-sectionally. } \\
\text { 2. However, the graft is not divided completely } \\
\text { into } 2 \text { parts; therefore, it is almost double } \\
\text { the length of the original graft and has a } \\
\text { thickness of approximately } 1.5 \mathrm{~mm} \text {. }\end{array}$ & $\begin{array}{l}\text { It extends the dimension } \\
\text { of the graft to almost twice } \\
\text { its size }\end{array}$ & Require a thick graft \\
\hline $\begin{array}{l}\text { McLeod et al. } \\
(2009)^{38}\end{array}$ & $\begin{array}{l}\text { A sharp back-action chisel helps in deep epithe- } \\
\text { lialization of palatal site from the mesial side } \\
\text { of canine to distal side of 1st molar. After deep } \\
\text { epithelialization, the SCTG is harvested with a } \\
\text { surgical blade in the manner used to harvest a } \\
\text { conventional free gingival graft. }\end{array}$ & $\begin{array}{l}\text { 1. Procurement of thin } \\
\text { uniform and abundant } \\
\text { CT graft from the palate } \\
\text { 2. Handling characteris- } \\
\text { tics of the graft com- } \\
\text { pared to SCTG obtained } \\
\text { in a conventional way } \\
\text { 3. It avoids CT perforation } \\
\text { at the donor site }\end{array}$ & $\begin{array}{l}\text { Postoperative bleeding and } \\
\text { pain }\end{array}$ \\
\hline
\end{tabular}


Table 3: (Continued)

\begin{tabular}{|c|c|c|c|}
\hline Author (year) & Harvesting technique & Advantage & Disadvantage \\
\hline $\begin{array}{l}\text { Kumar A et al. } \\
(2013)^{39}\end{array}$ & $\begin{array}{l}\text { Modified single incision technique } \\
\text { 1. A single incision is given } 2 \text { mm below to the } \\
\text { margin of the gingiva. For } 1^{\text {st }} \text { incision, the } \\
\text { blade was placed parallel along the long axis } \\
\text { of the palatal surface for the elevation of the } \\
\text { split-thickness flap. } \\
\text { 2. Then, through the same incision angle of } \\
\text { the blade made perpendicular to the palatal } \\
\text { tissue surface and continued to the bone. } \\
\text { 3. Followed by this incision, subepithelial con- } \\
\text { nective tissue graft was harvested from the } \\
\text { bone with the use of the periosteal elevator. } \\
\text { 4. Then at the mesial and distal side of graft, } 2 \\
\text { vertical incisions were given followed by one } \\
\text { horizontal medial incision made underlying } \\
\text { split-thickness flap, to separate it from the } \\
\text { adjacent tissue. } \\
\text { The 'Barraquer cataract knives' and 'AVS } \\
\text { blade' are the special blades used to make } \\
\text { vertical and horizontal incisions. }\end{array}$ & $\begin{array}{l}\text { Initially, little bleeding } \\
\text { occurred. The flap was } \\
\text { thick enough to reduce the } \\
\text { chances of damaging and } \\
\text { sloughing. }\end{array}$ & $\begin{array}{l}\text { Special instruments are } \\
\text { required }\end{array}$ \\
\hline $\begin{array}{l}\text { Reino et al. } \\
(2013)^{40}\end{array}$ & $\begin{array}{l}\text { Palatal Harvesting technique } \\
\text { 1. The incision was placed according to the } \\
\text { modified single incision technique sug- } \\
\text { gested by Lorenzana. } \\
\text { 2. Determination of length of incision was } \\
\text { done through graft dimension required. } \\
\text { 3. Reflection of the mucoperiosteal flap of } \\
\text { 1-2 mm was done with the help of a small } \\
\text { elevator followed by split-thickness flap } \\
\text { reflection. } \\
\text { 4. By keeping the periosteum intact on bone } \\
\text { and part of connective tissue with muco- } \\
\text { periosteal or split-thickness flap in respect } \\
\text { to maintain the graft thickness } \\
\text { 5. Approximately } 1.5 \text { mm wide graft harvested }\end{array}$ & $\begin{array}{l}\text { 1. This technique yields a } \\
\text { good amount of healing } \\
\text { and provides mini- } \\
\text { mum discomfort to the } \\
\text { patients. } \\
\text { 2. It allows higher control } \\
\text { over the graft thickness. } \\
\text { 3. It permits primary } \\
\text { wound closure and } \\
\text { better control of graft } \\
\text { thickness. }\end{array}$ & Technique sensitive \\
\hline $\begin{array}{l}\text { Bhatavadekar } \\
(2018)^{41}\end{array}$ & $\begin{array}{l}\text { Controlled Palatal Harvesting (CPH) technique } \\
\text { 1. An incision is given } 2 \text { mm below to mar- } \\
\text { gin of gingiva from } 1^{\text {st }} \text { molar using a No. } 15 \\
\text { scalpel blade. } \\
\text { 2. A vertical L-shaped incision is given at the } \\
\text { anterior end of the first incision with an } \\
\text { anterior release. } \\
\text { 3. It improves visibility and dexterity during } \\
\text { harvesting of the connective tissue graft. } \\
\text { The thick partial-thickness flap was elevated } \\
\text { leaving behind a thin periosteum covering } \\
\text { the palatal bone. } \\
\text { 4. The entire thickness of the flap is held with } \\
\text { the use of tissue forceps and then the con- } \\
\text { nective tissue graft was harvested. }\end{array}$ & $\begin{array}{l}\text { 1. Adequate control was } \\
\text { achieved to obtain good } \\
\text { visibility } \\
\text { 2. Better predictability in } \\
\text { ensuring adequate graft } \\
\text { and flap thickness } \\
\text { 3. Ensure even and uni- } \\
\text { form thickness of graft } \\
\text { and flap } \\
\text { 4. Minimum chance of } \\
\text { leaving behind a thin } \\
\text { flap for wound closure } \\
\text { at the donor site as it } \\
\text { minimizes necrosis and } \\
\text { sloughing of the flap } \\
\text { and improves grafting } \\
\text { success. }\end{array}$ & $\begin{array}{l}\text { 1. It is technique-sensitive } \\
\text { and requires a surgeon's } \\
\text { skill } \\
\text { 2. For harvesting; it de- } \\
\text { pends on the thickness } \\
\text { of the palatal mucosa. }\end{array}$ \\
\hline
\end{tabular}


Harvesting techniques for SCTG from the tuberosity (Table 4)

\section{Table 4: Techniques for SCTG harvesting from the tuberosity}

\begin{tabular}{|c|c|}
\hline Author (year) & Harvesting technique \\
\hline Hirsch et al. (2001) ${ }^{42}$ & $\begin{array}{l}\text { The SCTG is harvested from the tuberosity region as a combined procedure of pocket reduc- } \\
\text { tion and esthetic root coverage. When the } 2 \text { approaches are combined like this, it removes the } \\
\text { need for a second surgical site. }\end{array}$ \\
\hline Jung et al. (2008)43 & $\begin{array}{l}\text { The authors advocate harvesting subepithelial connective tissue from the tuberosity area, } \\
\text { obtained by gingivectomy. The donor soft tissue is deep epithelialized and trimmed. This tech- } \\
\text { nique results in fewer complications, rapid hemostasis, and minimal tissue contraction (dense } \\
\text { connective tissue) of the graft; tissue contraction commonly occurs with palatal grafts. }\end{array}$ \\
\hline Zuhr and Hürzeler (2012) ${ }^{44}$ & $\begin{array}{l}\text { Two converging incisions are given distally to last molar afar while remaining within the mas- } \\
\text { ticatory mucosa. Incisions are given 1.0-1.5 mm deep perpendicular to the surface of the tissue. } \\
\text { Then a partial-thickness incision is made buccally and palatally, till the mesial surface of the } \\
\text { last molar, for harvesting uniform and even partial-thickness flap. A subperiosteal incision is } \\
\text { given to harvesting a wedge-shaped SCTG with use of sharp dissection. }\end{array}$ \\
\hline
\end{tabular}

Amin PN et al. (2018) ${ }^{45}$ in their study compared palatal and tuberosity as a donor site for grafting of soft tissue associated with postoperative pain. They evaluated the outcomes of recipient and donor sites. The authors stated that graft harvested from the tuberosity site may ensure a better choice than graft from the palatal donor site concerning function and minimal postoperative pain.

\section{Potential complications of the SCTG- \\ Donor site complications (Petrungaro P 2002) 46 $^{46}$}

1. Necrosis of connective tissue graft and palatal donor site

2. More bleeding associated with pain and discomfort to the patient

3. Increased chances of disease at the donor site

4. Rarely seen loss of sensation in the palate

\section{Recipient site complications}

1. Postsurgical swelling and ecchymosis (Müller HP 1999) $)^{47}$

2. External root resorption (Hokett SD 2001) $)^{48}$

3. Gingival cysts (Breault LG 1997) ${ }^{49}$

4. Gingival soft tissue abscess

5. Exostosis (Corsair AJ 2001) $)^{50}$

6. Graft loss

7. Epithelial cell discharge (Parashis AO 20017) ${ }^{51}$

8. Reaction to suture material (Vastardis S 2003) ${ }^{52}$

9. Gingival cul-de-sac defects (Wei PC 2003) (53 $^{5}$

10. Suturing under tension, thereby impinging on microcirculation (Sanz M 2014) ${ }^{26}$

Harvesting of thin connective tissue graft is a very challenging task and may cause trauma to the neurovascular bundle. A thin masticatory mucosa may harvest SCTG with several elements of rete pegs which penetrate through connective tissue pegs which is of the multi-layered epithelium. It causes transplanted graft rejection (Harris, 2003). ${ }^{54}$ To augment and gain in the thickness of connective tissue of donor site is made through biostimulation of fibroblasts with the use of collagen biomaterial (Rocha et al., 2012). ${ }^{55}$

Bednarz $\mathrm{W}^{56}$ in their study clinically and histologically evaluated the technique to augment thin palatal tissue. The author stated that the use of Biokol $\AA$ or Gel $0 \AA$ collagen materials augment thin masticatory mucosa and ensure significant mucosa thickening.

\section{DISCUSSION}

A sub-epithelial connective tissue graft is considered as a gold standard from ancient times. Application of SCTG for numerous periodontal surgeries have shown predictable results. Various authors introduced numerous harvesting methods of SCTG with innovation in designs, accessibility along with subjective comfort and concerns. Still, the research studies are going on continuously to put forward a novel technique for harvesting. Every technique has its indications, advantages and disadvantages. To use any method it depends upon some factors such as the amount of graft needed and anatomical site. ${ }^{26}$

As, from the clinical perspective point, the presence of epithelium on the graft or not is also an important first factor. It has been observed from many previous studies that both the grafts have achieved predictable outcomes which depends on the blood supply of the recipient site and also on surgical skills.

The second factor is the type and number of incisions. Some authors have proposed that vertical incision achieve better access but some authors believe not to use vertical incisions as they cause necrosis or hampering of blood supply. Initially, some authors have given single incision technique but due to its certain limitations, they modified it. The other factors such as visibility, accessibility and healing wound are the im- 
portant considerations for the successful results of harvesting graft. By achieving good access and control, it may procure graft of uniform thickness. ${ }^{57}$

Though there are numerous evolutions in harvesting technique of connective tissue graft but still in today's scenario it requires more research. The ideal method for harvesting the graft should be comfortable for the patients as well as surgeon and less time-consuming. In future, investigations or researchers are required to evaluate the most efficient and proper technique for harvesting the graft. Thus the randomized clinical trials and systematic reviews are required to study the outcomes of different methods.

\section{CONCLUSION}

A connective tissue graft is a skilful treatment method in periodontal plastic surgery and peri-implant soft tissue plastic surgery. Harvesting techniques that are minimally traumatic but aimed at maximizing tissue volume ensure multi-purpose usability of connective tissue graft. The unique nature of this tissue enables its use in multiple clinical scenarios. The easy availability, low cost, and proven efficacy of SCTGs compared to other regenerative techniques have made this a valuable approach to periodontal plastic surgery. The superior esthetics and predictable outcomes obtained through SCTG is the gold standard for treatment of root coverage.

Acknowledgement: Authors acknowledge the immense help received from the scholars whose articles are cited and included in references to this manuscript. The authors are also grateful to authors/editors / publishers of all those articles, journals and books from where the literature for this article has been reviewed and discussed.

Source(s) of Funding: The authors do not have any financial interest in the companies whose materials are included in this article

Conflicting Interest: The authors have no conflict of interest

\section{REFERENCES}

1. Miller JP. Regenerative and reconstructive periodontal plastic surgery. Mucogingival surgery. Dental Clinics of North America. 1988 Apr;32(2):287-306.

2. Allen EP. Use of mucogingival surgical procedures to enhance esthetics. Dental Clinics of North America. 1988 Apr;32(2):307330.

3. Bjorn H. Free transplantation of gingiva propria. Swed Dent $\mathbf{J}$ 1963: 22: 684-689.

4. Harvey PM. Management of advanced periodontitis. I. Preliminary report of a method of surgical reconstruction. The New Zealand Dental Journal. 1965 ;61(285):180.

5. Miller Jr PD. Root coverage using the free soft tissue autograft following citric acid application. III. A successful and predictable procedure in areas of deep-wide recession. Int. J. Periodont. Rest. Dent. 1985;5:14-36.
6. Grupe HE, Warren RF. Repair of gingival defects by a sliding flap operation. The Journal of Periodontology. 1956;27(2):92-5.

7. Cohen DW, Ross SE. The double papillae repositioned flap in periodontal therapy. The Journal of Periodontology. 1968;39(2):65-70.

8. Edel A. Clinical evaluation of free connective tissue grafts used to increase the width of keratinised gingiva. Journal of clinical periodontology. 1974;1(4):185-196.

9. Langer B, Calagna L. The subepithelial connective tissue graft. The Journal of prosthetic dentistry. 1980;44(4):363-367.

10. Langer B, Langer L. Subepithelial connective tissue graft technique for root coverage. Journal of periodontology. 1985;56(12):715-720.

11. Bouchard P, Malet J, Borghetti A. Decision-making in aesthetics: root coverage revisited. Periodontology 2000;27(1):97-120.

12. Allen AL. Use of the supraperiosteal envelope in soft tissue grafting for root coverage. I. Rationale and technique. International Journal of Periodontics and Restorative Dentistry. 1994;14(3).

13. Harris RJ. Successful root coverage: a human histologic evaluation of a case. International Journal of Periodontics and Restorative Dentistry. 1999;19(5).

14. Zuhr O, Bäumer D, Hürzeler M. The addition of soft tissue replacement grafts in plastic periodontal and implant surgery: Critical elements in design and execution. Journal of clinical periodontology. 2014;41:S123-142.

15. Harris RJ. A comparison of two techniques for obtaining a connective tissue graft from the palate. International Journal of Periodontics and Restorative Dentistry. 1997;17(3).

16. Karthikeyan BV, Khanna D, Chowdhary KY, Prabhuji ML. The versatile subepithelial connective tissue graft: A literature update. General dentistry. 2016;64(6):e28-33.

17. Bassetti RG, Stähli A, Bassetti MA, Sculean A. Soft tissue augmentation procedures at second-stage surgery: a systematic review. Clinical oral investigations. 2016;20(7):1369-1387.

18. Poskevicius L, Sidlauskas A, Galindo-Moreno P, Juodzbalys G. Dimensional soft tissue changes following soft tissue grafting in conjunction with implant placement or around present dental implants: A systematic review. Clinical oral implants research. 2017;28(1):1-8.

19. Müller HP, Eger T. Masticatory mucosa and periodontal phenotype: A review. International Journal of Periodontics and Restorative Dentistry. 2002;22(2).

20. Reiser GM, Bruno JF, Mahan PE, Larkin LH. The subepithelial connective tissue graft palatal donor site: anatomic considerations for surgeons. International Journal of Periodontics and Restorative Dentistry. 1996;16(2).

21. Borle, R.M., A. Jadhav, N. Bhola, P. Hingnikar, and P. Gaikwad. "Borle's Triangle: A Reliable Anatomical Landmark for Ease of Identification of Facial Nerve Trunk during Parotidectomy." Journal of Oral Biology and Craniofacial Research 9,(2019): 33-36.

22. Dangore-Khasbage, S., and R. Bhowate. "Utility of the Morphometry of the Maxillary Sinuses for Gender Determination by Using Computed Tomography." Dental and Medical Problems 55, no. 4 (2018): 411-17.

23. Klosek SK, Rungruang T. Anatomical study of the greater palatine artery and related structures of the palatal vault: considerations for palate as the subepithelial connective tissue graft donor site. Surgical and radiologic anatomy. 2009;31(4):245-250.

24. Mörmann W, Schaer F, Firestone AR. The Relationship Between Success of Free Gingival Grafts and Transplant Thickness: Revascularization and Shrinkage-A One Year Clinical Study. Journal of Periodontology. 1981;52(2):74-80.

25. Hirsch A, Attal U, Chai E, Goultschin J, Boyan BD, Schwartz $\mathrm{Z}$. Root coverage and pocket reduction as combined surgical procedures. Journal of periodontology. 2001;72(11):1572-1579. 
26. Sanz M, Simion M, Abbas F, Aroca S, Artzi Z, Burkhardt R, Cortellini P, Demirel K, Monnet Corti V, Ortiz-Vigon A, Rasperini G. Surgical techniques on periodontal plastic surgery and soft tissue regeneration: consensus report of Group 3 of the 10th European Workshop on Periodontology. Journal of clinical periodontology. 2014;41:S92-97.

27. Dambhare, A., M.L. Bhongade, P.V. Dhadse, B. Sehdev, K.K. Ganji, K. Thakare, H. Murakami, Y. Sugita, H. Maeda, and M.K. Alam. "A Randomized Controlled Clinical Study of Autologous Platelet Rich Fibrin (PRF) in Combination with HA and BetaTCP or HA and Beta-TCP Alone for Treatment of Furcation Defects." Journal of Hard Tissue Biology 28,(2019): 185-90.

28. Nery EB, Corn H, Eisenstein IL. Palatal exostosis in the molar region. Journal of periodontology. 1977;48(10):663-666.

29. Liu CL, Weisgold AS. Connective tissue graft: a classification for incision design from the palatal site and clinical case reports. International Journal of Periodontics and Restorative Dentistry. 2002;22(4).

30. Raetzke PB. Covering localized areas of root exposure employing the "envelope" technique. Journal of periodontology. 1985;56(7):397-402.

31. Harris RJ. The connective tissue and partial thickness double pedicle graft: A predictable method of obtaining root coverage. Journal of periodontology. 1992;63(5):477-486.

32. Hürzeler MB, Weng D. A single-incision technique to harvest subepithelial connective tissue grafts from the palate. International Journal of Periodontics and Restorative Dentistry. 1999;19(3).

33. Bruno JF. Connective tissue graft technique assuring wide root coverage. Int J Periodontics Restorative Dent. 1994;14(2):126137.

34. Lorenzana ER, Allen EP. The single-incision palatal harvest technique: a strategy for esthetics and patient comfort. Int J Periodontics Restorative Dent. 2000;20(3):297-305.

35. Del Pizzo M, Modica F, Bethaz N, Priotto P, Romagnoli R. The connective tissue graft: a comparative clinical evaluation of wound healing at the palatal donor site. A preliminary study. J Clin Periodontol. 2002;29(9):848-854.

36. Bosco AF, Bosco JM. An alternative technique to the harvesting of a connective tissue graft from a thin palate: enhanced wound healing. Int J Periodontics Restorative Dent. 2007;27(2):133139.

37. Ribeiro FS, Zandim DL, Pontes AE, Mantovani RV, Sampaio JE, Marcantonio E. Tunnel technique with a surgical maneuver to increase the graft extension: case report with a 3-year followup. J Periodontol. 2008;79(4):753-758.

38. McLeod DE, Reyes E, Branch-Mays G. Treatment of multiple areas of gingival recession using a simple harvesting technique for autogenous connective tissue graft. J Periodontol. 2009;80(10):1680-1687.

39. Kumar A, Sood V, Masamatti SS, Triveni MG, Mehta DS, Khatri M, Agarwal V. Modified single incision technique to harvest subepithelial connective tissue graft. Journal of Indian Society of Periodontology. 2013;17(5):676.

40. Reino DM, Novaes Jr AB, Grisi MF, Maia LP, Souza SL. Palatal harvesting technique modification for better control of the connective tissue graft dimensions. Brazilian dental journal. 2013;24(6):565-568.
41. Bhatavadekar NB, Gharpure AS. Controlled Palatal Harvest Technique for Harvesting a Palatal Subepithelial Connective Tissue Graft. Compendium of continuing education in dentistry (Jamesburg, NJ: 1995). 2018;39(2):e9-12.

42. Hirsch A, Attal U, Chai E, Goultschin J, Boyan BD, Schwartz Z. Root coverage and pocket reduction as combined surgical procedures. J Periodontol. 2001;72(11):1572-1579

43. Jung UW, Um YJ, Choi SH. Histologic observation of soft tissue acquired from maxillary tuberosity area for root coverage. J Periodontol. 2008;79(5):934-940.

44. Zuhr O, Hürzeler M. Plastic-Esthetic Periodontal and Implant Surgery: A Microsurgical Approach.Hanover Park, IL: Quintessence; 2012.

45. Amin PN, Bissada NF, Ricchetti PA, Silva AP, Demko CA. Tuberosity versus palatal donor sites for soft tissue grafting: A splitmouth clinical study. Quintessence International. 2018 ;49(7).

46. Petrungaro P. Using platelet rich plasma to accelerate soft tissue maturation in esthetic periodontal surgery. Compend Contin Educ Dent. 2001;22(9):729-732, 734, 736 passim.

47. Müller HP, Stahl M, Eger T. Root coverage employing an envelope technique or guided tissue regeneration with a bioabsorbable membrane. J Periodontol. 1999;70(7):743-751.

48. Hokett SD, Peacock ME, Burns WT, Swiec GD, Cuenin MF. External root resorption following partial-thickness connective tissue graft placement: a case report. J Periodontol. 2002;73(3): 334-339.

49. Breault LG, Billman MA, Lewis DM. Report of a gingival "surgical cyst" developing secondarily to a subepithelial connective tissue graft. J Periodontol. 1997;68(4):392-395.

50. Corsair AJ, Iacono VJ, Moss SS. Exostosis following a subepithelial connective tissue graft.J Int Acad Periodontol. 2001;3(2):38-41.

51. Parashis AO, Tatakis DN. Subepithelial connective tissue graft for root coverage: a case report of an unusual late complication of epithelial origin. J Periodontol. 2007;78(10):2051-2056.

52. Vastardis S, Yukna RA. Gingival/soft tissue abscess following subepithelial connective tissue graft for root coverage: report of three cases. J Periodontol. 2003;74(11):1676-1681.

53. Wei PC, Geivelis M. A gingival cul-de-sac following a root coverage procedure with a subepithelial connective tissue submerged graft. J Periodontol. 2003;74(9):1376-1380.

54. Harris RJ. Histologic evaluation of connective tissue grafts in humans. International journal of periodontics and restorative dentistry. 2003;23(6).

55. Rocha AL, Shirasu BK, Hayacibara RM, Magro-Filho O, Zanoni JN, Araújo MG. Clinical and histological evaluation of subepithelial connective tissue after collagen sponge implantation in the human palate. Journal of periodontal research. 2012;47(6):758-765.

56. Bednarz W, Kobierzycki C, Dzięgiel P, Botzenhart U, Gedrange T, Ziętek M. Augmentation of the hard palate thin masticatory mucosa in the potential connective tissue donor sites using two collagen materials - Clinical and histological comparison. Annals of Anatomy-Anatomischer Anzeiger. 2016;208:78-84.

57. Puri K, Kumar A, Khatri M, Bansal M, Rehan M, Siddeshappa ST. The 44-year journey of palatal connective tissue graft harvest: A narrative review. Journal of Indian Society of Periodontology. 2019;23(5):395. 